\title{
Opening Remarks For The Symposium
}

\author{
V. B. BROOKS
}

It is a great pleasure to welcome all participants and members of the audience on behalf of the Organizing Committee of this Symposium. John Girvin, Bob Lee and I hope that joint considerations of basic and clinical problems in Neuroscience will become a regular feature from now on at this Annual Canadian Congress of Neurological Sciences, with participation by members of the Society for Neuroscience.

We have the good fortune to have in our midst Professor Charles Phillips, who has done so much to advance our understanding of motor neurophysiology. "Motor Control" re-emerged as a focus of enquiry in the sixties, following a period of preoccupation with regional and cellular problems. The growing interest (and probably knowledge) is documented by the graph in Figure 1, of the number of meetings devoted to this topic during the-past decade. The cumulative curve seems to follow the well-known logistic pattern, characteristic of all growth in an environment with limits, shown also in Figure 2a A. Although we have limits in number of labs, positions and money, I doubt that we have already passed the peak of basic research participation as outlined by the broken curve $P$ in Figure $2 a$. And, I am sure we all agree that there are many interesting basic ideas to be uncovered yet (cf. curve I in Figure $2 \mathrm{a}$ ).

We may be near the mid-point of the growth curve, (i.e. the origin of

From the Department of Physiology, University of Western Ontario, London, Canada.

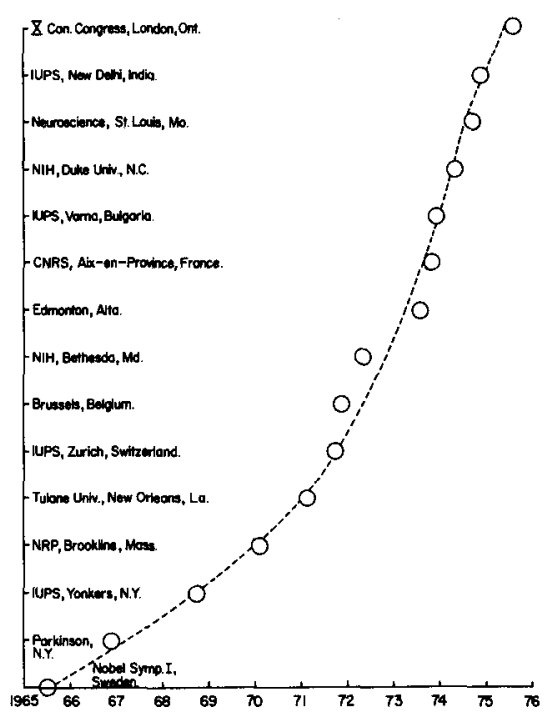

Figure 1-Meetings on "Motor Control" during the past decade plotted as a cumulative time histogram. The trend line is drawn in by hand. Meetings are identified on ordinate, and details appear in Table 1.

Figure 2b), around which a period of "crises" usually arises that determines whether the field goes on to senescence or rejuvenation (cf. De
Solla Price, 1963; Holton, 1973). Following Kuhn's terminology (1970) we could say that we have had an intense period of data gathering with many new methods in all participating sciences, that has led to successive formulations of paradigms. Their tests during the past decade against clinical and experimental realities have revealed anomalies that we cannot yet pull together. We stand a good chance of resolving these "crises", with input from theoretical, basic and clinical disciplines. New theories will emerge that hopefully will "escalate" the progress of our interdisciplinary field in the manner drawn by Holton (1973) in Figures $2 b$ and $c$. The limitation in this sort of Neuroscience of course resides in the models of how we imagine the brain works. This Symposium contains many germinal papers, attesting to the healthy state of turmoil of our subject; who knows, we might be tilting towards "conceptual revolutions" in these very sessions! At any rate, we all look forward to continued and new levels of vigour of discovery in our subject: "Motor Control".
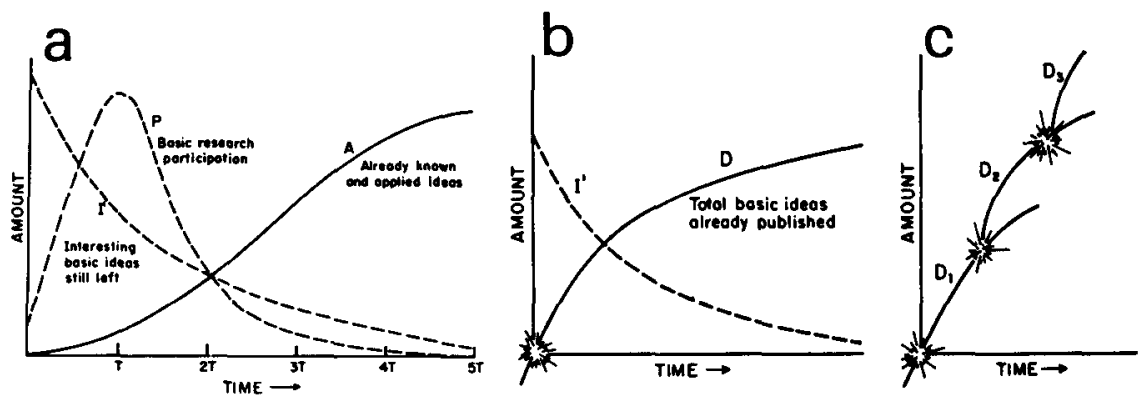

Figure 2-(a) Inverse relationship between the accumulation of application and the interest in a basic-research field.

(b) and (c) The escalation of discovery lines.

(Modified, with permission, from Holton, 1973). 
Table 1 Details of meetings and resulting publications on "Motor Control" plotted in Fig. 1.

1965: GRANIT, R. (Ed.) (1966). Muscular Afferents and Motor Control. John Wiley and Sons, New York and Almqvist \& Wiksell, Stockholm. Proceedings of the First Nobel Symposium held at Södergarn, Stockholm, June 1965.

1966: YAHR, M. D. AND PURPURA, D. P. (Eds.) (1967). Neurophysiological Basis of Normal and Abnormal Motor Activities. Raven Press, New York. Proceedings of the Third Symposium of the Parkinson's Disease Information and Research Center, Columbia University, November 1966. Sponsored jointly by the National Institute of Neurological Diseases and Blindness, National Institutes of Health, U.S. Public Health Service, and the Parkinson's Disease Foundation.

1968: BROOKS, V. B., JASPER, H. H., PATTON, H. D., PURPURA, D. P. AND BROOKHART, J. M. (1970). Symposium on Cerebral and Cerebellar Motor Control. Brain Research, 17, 539-552.

Satellite Symposium of the XXIV International Physiological Congress held in Yonkers, N.Y., August 1968.

1970: EVARTS, E. V., BIZZI, E., BURKE, R. E., DELONG, M. AND THACH, W. T. (Eds.) (1970). Central Control of Movements. Neurosciences Research Symposium Summaries, Vol. 6. MIT Press, Cambridge, Mass. A report based on an NRP Work Session held at Brookline, Mass., January 1970.

1971: MASER, Jack D. (Ed.) (1973). Efferent Organization and the Integration of Behavior. Academic Press, New York.

Proceedings of a meeting held at Tulane and Loyola Universities, New Orleans, La.

1971: AKERT, K., BUSER, P., WIESENDANGER, M. AND MOSFELDT LAURSEN, A. (Eds.) (1972). Neural Control of Motor Performance. Brain Research, 40, 1-202.

Satellite Symposium of the XXV International Physiological Congress, held in Zurich, Switzerland, August 1971.

1971: DESMEDT, J. E. (Ed.) (1973). Human Reflexes. Pathophysiology of Motor Systems. Methodology of Human Reflexes. New Developments in Electromyography and Clinical Neurophysiology, Vol. 3. S. Karger, Basel.

From a meeting held in Brussels, Belgium, September 1971.

1972: GRANIT, R. AND BURKE, R. E. (1973). The Control of Movement and Posture. Brain Research, 53, 1-28.

Report of a conference sponsored by the Fogarty International Center for Advanced Study in the Health Sciences, National Institutes of Health, Bethesda, Md., and held in Bethesda, Md., March 1972.

1973: STEIN, R. B., PEARSON, K. G., SMITH, R. S. AND REDFORD, J. B. (Eds.) (1973). Control of Posture and Locomotion. Plenum Press, New York. Proceedings of an International Symposium at the University of Alberta, Edmonton, Alberta, August 1973.

1973: PAILlARD, J. AND MASSION, J. (Eds.) (1974). Motor aspects of Behaviour and Programmed Nervous Activities. Brain Research, 71, 189-575.

Colloques Internationaux du Centre National de la Recherche Scientifique, Aix-enProvence, September 1973.

1973: GYDIKOV, A. A., TANKOV, N. T. AND KOSAROV, D. S. (Eds.) (1973). Motor Control. Plenum Press, New York, 1973.

Selected papers from a regional meeting of IUPS held in Varna, Bulgaria, October 1973.

1974: Duke University (Not Published). G. Somjen, organizer. Symposium on Motor Control in the Mammalian CNS (NIH Training Session), April 1974.

1974: EVARTS, E. V. (Ed.) (1975). Motor programs and feedback in control of movement. Brain Information Service Conference Report No. 38, March 1975.

Symposium held during Fourth Annual Meeting of the Society for Neuroscience in St. Louis, Mo., November 1974.

1974: Suprasegmental Control of Movement (1974). Proceedings of the International Union of Physiological Sciences, $\mathrm{X}, 140-146$.

Satellite symposium of the XXVI International Physiological Congress held in New Delhi, India, September 1974.

1975: BROOKS, V. B., GIRVIN, J. AND LEE, R. (Eds.) (1975). Mechanisms in Motor Control. Canadian Journal of Neurological Sciences: 2, 219-322.

Symposia on Clinical and Basic Research in Neuroscience. Papers from the Tenth Canadian Congress of Neurological Sciences in association with the Canadian Chapters of the Society for Neuroscience, held in London, Ontario, June 1975.

\section{REFERENCES}

1963: DE SOLLA PRICE, D. J. (1963). Little Science, Big Science. Columbia University Press, New York and London, 119 pp.

1973: HOLTON, G. (1973). Thematic Origins of
Scientific Thought, Kepler to Einstein. Harvard University Press, Cambridge, Mass., 493 pp.

1970: KUHN, T. S. (1970). The Structure of Scientific Revolutions. 2nd Edn. The University of Chicago Press, Chicago, 210 pp. 